[6] - The Design of Engineering Curricula. Paris, France: UNESCO, 1977. Contains a description of the systems of engineering education in seven countries.

[7] A. S. Knowles, Ed., The International Encyclopedia of Higher Education. San Francisco, CA: Jossey-Bass Publishers, 1977. A description of the systems of higher education in 198 countries and territories are included in this 10 volume set.

[8] Minister of Education, Toutes ses Chances. Paris, France: Nov. 1977. Describes recent changes in the education system in France.
[9] M. J. Salmon, Ed. Situation of and Trends in Tertiary Education in Europe. Essex, England: North East London Polytechnic, Mar. 1976. Published on behalf of the Council of Europe.

[10] Secretary of State for Universities, Aprés le Baccalaureat. Paris, France: National Office of Information on Education and the Professions, 1977.

[11] USSR, Education. Moscow, USSR: Novosti Press Agency Publishing House, 1976.

[12] L'U.R.S.S., L'Enseignement Supérieur. Moscow, USSR : Novosti Press Agency Publishing House, 1976.

\title{
Continuing Education Around the World
}

\author{
JOHN P. KLUS AND JUDY A. JONES
}

Invited Paper

\begin{abstract}
Continuing education programs in socialist countries, developing countries, and under French Law 575, with respect to engineering, are discussed. The design of programs depends on cultural, economic, and political pressures. Postecondary education in socialist countries was influenced by the need to meet demands for trained personnel, by the assumption that it is cheaper to educate the employed, and by continuing education's ability to mix practice with theory. Continuing education in the socialist countries is available through full-time study, part-time study, and independent study with or without supervision. Under French Law 575 continuing education is funded through the State and the employer, with the employer contributing 1 percent of total wages, creating a 5700 million franc fund in 1975. Developing countries have a different emphasis, centering on nural technologies, technician rather than engineer education, and teacher education. The role of the individual, universities, governments, and firms in financing and sponsoring continuing education is placed in worldwide perspective. Lectures in their various formats, correspondence courses, satellite communications, and audiovisual media instructional utility are reviewed. The success or failure of continuing education programs in one country cannot be easily translated into what will happen in another country. All in all, continuing education is more highly regarded worldwide at this point in time than ever before.
\end{abstract}

\section{INTRODUCTION}

$\mathrm{D}$ ESIGN of a continuing education course that can meet local conditions and needs is always a problem. A university professor in Canada will find his task very different from that of a professional society course director in Denmark. The measure of success for both will be how well they can adapt general principles of course design to their own situations.

Continuing education is an integral part of human culture. As new technology influences the economic development equation, there is constant need to keep the engineering

Manuscript received February 2, 1978.

The authors are with the Department of Engineering, University of Wisconsin-Extension, Madison, WI 53706. profession up to date. Highly developed countries can meet this need with large cash investments, but many developing countries are hard-pressed to supply even good primary education, and continuing education investments are hard to justify. Still, it is a poor strategy for these countries not to maintain the qualifications of those they do send through college.

Political structure and tradition also exert heavy influence on program design. Socialist countries tend to be highly organized, planning out programs that are financed by government and/or government-controlled industry. Course directors can devote more time to quality control, with less worry over financing. In capitalistic countries financial concerns make accurate needs analysis critical. Individuals sign up largely as a matter of choice, with little influence from their employers other than financial support. In either case, capitalist or socialist, conditions from one country to another are significantly different. You cannot predict that a course will succeed all over the world simply because it succeeded in the United Kingdom.

This paper will attempt to describe the methods of continuing education in socialist countries, the influence of the French Law on continuing education, and other unique studies and situations. We will also discuss financing and organizational structure.

\section{Unioue Situations}

\section{European Socialist Countries}

Continuing education in European socialist countries was summarized in a 1975 document, Post-Secondary Education of Persons Already Gainfully Employed in European Socialist Countries, prepared by Professor Janus Tymowski of the Warsaw Technical University in collaboration with Franciszek Januszkiewicz of the Research Institute of Science Policy and 
Higher Education (Warsaw). ${ }^{1}$ Post-secondary education of employed persons in Bulgaria, Czechoslovakia, the German Democratic Republic (GDR), Poland, Yugoslavia, Romania, Hungary, and the Soviet Union (USSR) was defined in this document to include those studies at the post-secondary level which lead to a degree or diploma.

After World War II, the prevailing opinion in most socialist countries was that post-secondary education for adults was an expedient way to meet temporary needs. They thought that once the universities were rebuilt, adult education would not be needed. However, it soon became evident that not enough students were graduating from full-time programs to meet the needs of employers. Therefore post-secondary education for employed persons became part of the total education system.

A second factor influencing the growth of these studies was that from 1950 to 1965 , USSR economists considered it inexpensive to educate the employed, a view accepted toward the end of the fifties by other socialist countries. Hence the number of employed students systematically increased until the exaggerated demands upon facilities caused the level of participation to drop off by 1968 . A third factor favoring the growth of post-secondary adult education was that it tended to mix theory and practice whereas full-time programs tended only to teach theory.

Post-secondary studies may be pursued in several ways. Full-time students, those who worked after secondary school and now wish to resume full-time studies, may be given a government scholarship to return to school, or their employer may pay for their studies provided the employee returns to his job once his education is completed.

Part-time students attend classes in the afternoon or evening. Their curriculum is similar to that for full-time students, but an extra year is needed for completion. Classes are normally held for four hours, four times a week. Because part-time studies require a more concentrated effort, participation is low.

Extramural studies are the most prevalent format. Using textbooks, study guides, and other materials, participants study independently. Regular attendance is required at consultation sessions with faculty of the local university. Consultation sessions may take the form of seminars or may be oriented to learning by electronic media.

External students receive no learning assistance from the university. They are simply given a syllabus and a list of compulsory exams. External studies are not popular and some countries have dropped them entirely.

Although specific data was difficult to obtain, Tymowski and Januszkiewicz did gather enough information from six European socialist countries to allow comparison of full time, part time, and extramural studies (Fig. 1) according to percentages of students enrolled. The overall number of students in post-secondary studies increased from 2895000 in 1960 to 5612000 in 1972 . Enrollments in extramural and part-time studies peaked around 1965, while that same year saw full-time enrollments bottoming out. More recently, full-time enrollments have been increasing, part-time enrollments remaining fairly constant, and extramural enrollments decreasing.

\footnotetext{
1J. Tymowski and F. Januszkiewicz, Post-Secondary Education of Persons Already Gainfully Employed in European Socialist Countries. Warsaw, Poland: UNESCO, 1975.
}

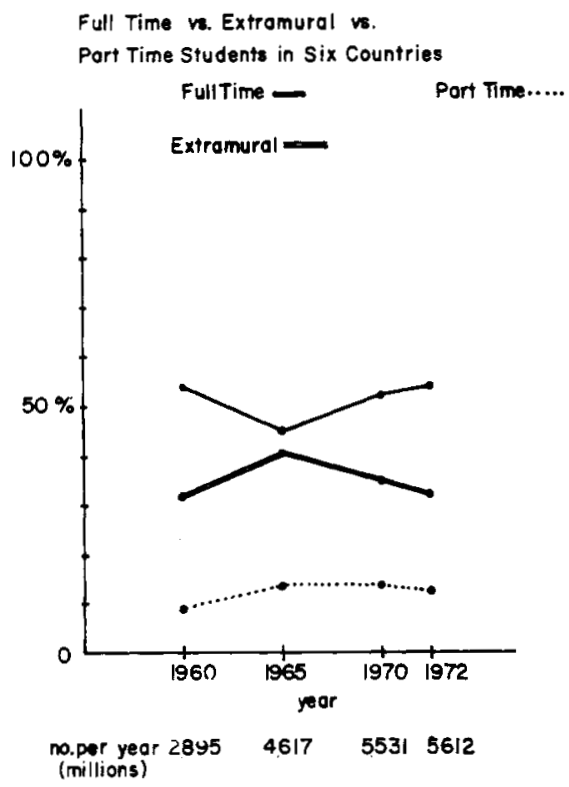

Fig. 1. Continuing education enrollment figures for six European Socialist countries.

Post-secondary studies are organized in a variety of locations. In the USSR, extramural studies and evening studies are conducted by two universities at their branch and consultative centers throughout the country. Classes are often held in large industries and on construction sites. In Poland the engineering schools provide evening studies and some extramural studies. Most adult education in the socialist countries is organized at higher education centers, at branch schools, in large cities, and in large industries.

Entrance requirements for admission to a post-secondary adult education program are a diploma from a secondary or technical trade school, and a recommendation from one's employer. The diploma requirement is equivalent to a (U.S.) high school diploma. As seen in Fig. 2, this would imply that students in Poland are at least 19, and probably older by the time work experience is acquired. Most students do have a background of work experience, since the education program and the person's job are closely related. This experience varies from "many years" to two years. In the GDR the prospective student must submit a paper outlining why he thinks he needs education beyond what he gets on the job. Sometimes, in addition to these documents, interviews and examinations are also held. The selections are not always made by the university. In Yugoslavia, where industry pays all student costs for education related directly to industry's development plans, industry decides who will participate. But universities have the final word on which of the selections will be accepted, usually screening them by work experience or competitive examinations.

The average age of students in socialist post-secondary adult education has been dropping. In the early years, most students were 35 or older. Lately, many students who were disappointed in their bid to enter a university immediately after secondary school have sought to continue their education by becoming employed and enrolling in post-secondary programs for the employed.

In post-secondary adult education, and extramural studies in particular, only 60-70 percent of the first-year students graduated. Graduation requirements are similar to those for 


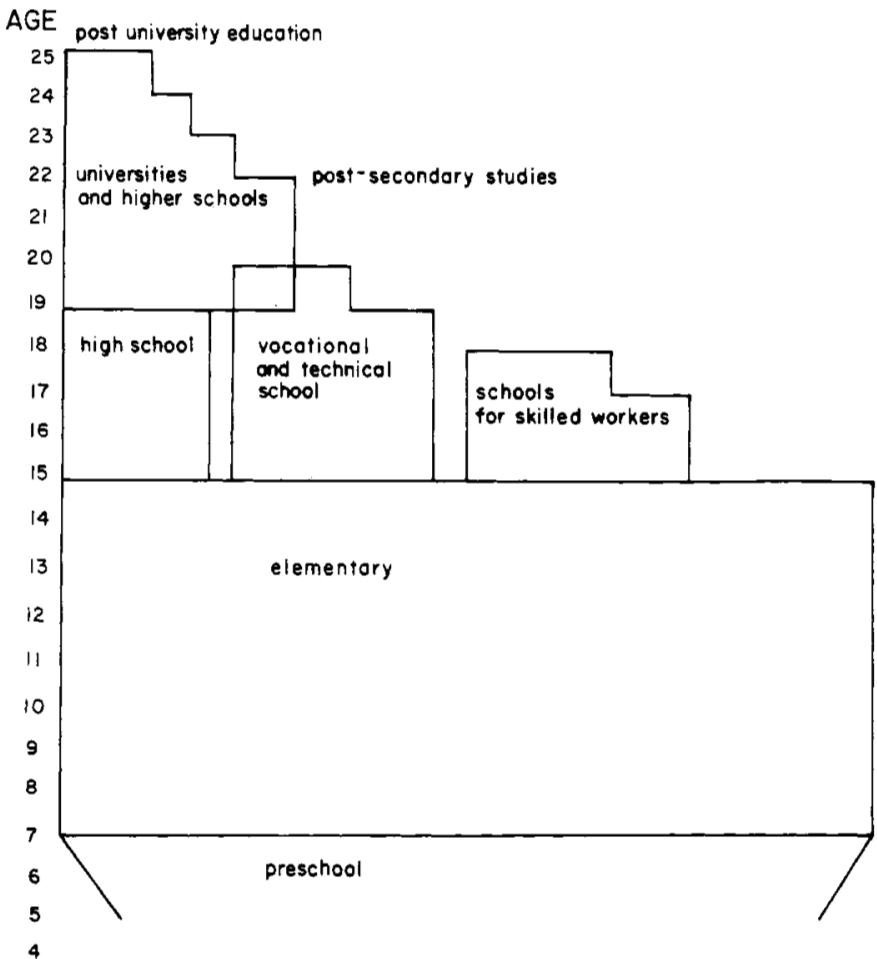

Fig. 2. The school system in Poland, 1974.

university students (where percent graduated is much higher), but the teaching of employed students in education programs is lower in quality. This is partly due to an inappropriate selection process. The instructors for part-time and extramural studies are often young and inexperienced in industry. More experienced university staff do not want to get involved because post-secondary education demands that instructors work inconvenient hours.

In order to bring the quality of adult education studies up to the level of full-time studies, Tymowski and Januszkiewicz have recommended several improvements. The most basic need is for more careful selection by employers of the employees who are to participate. Further, employee participation should be made easier by new media technologies, cassettes in particular. Extramural studies, when used properly, permit students to consult with specialists in their field, and attend laboratory seminars. Another condition necessary for improvements is that the students have enough work experience to appreciate and apply what they learn. Lastly, industry can help students by rotating their job assignments to coordinate with the study curriculum.

\section{French Legislation of 1971}

French Law 575 was passed in July 1971 culminating several years of cooperative work between industries and trade unions. It established a role for professional training in the context of lifelong education, and in effect governs continuing education. There are two main types of provisions in the 1971 law: those relating to the financing of continuing education, and those which are intended to organize its development.

The financing provisions were designed to support a training market with funds from two sources: the firms and the state. Firms having more than 10 employees must contribute at least 1 percent of their total wages bill to staff training.
Taken altogether, these provisions make for a large budget5700 million francs for France in 1975. Management and control of this big budget requires a complex procedure, so some rules were worked out to detail the types of expenditures allowed.

1) A firm may organize its own continuing education and finance it at all levels-salaries and social expenses of workers and teachers, costs of equipment, and operation of the centers -but the firm's training policy is subject to the criticism of the trade unions.

2) Payments may be made to an outside training body for continuing education activities organized for the firm's staff.

3) Indirectly, a firm may finance a training fund; for example, a profession might combine their efforts, or a firm may contribute up to 10 percent of their profits to an approved continuing education establishment.

If the total expenditure and contributions listed above are less than 1 percent, then the balance must be paid to the national treasury.

Some statistics have been collected on engineers. The larger the number of nonengineer employees in a firm, the higher is the percentage of them participating in continuing education. However, for engineers and senior staff, the reverse was found-smaller firms had a higher percentage of engineers and senior staff participating in continuing education than did larger firms. In addition, the percentage of engineers and senior staff participating has decreased since the 1971 law began-from 19 percent in 1972 to 15 percent in 1975. Both engineering schools and private training establishments compete for this market. The proportion done by the schools is unknown, but they do occupy a position of importance.

Although the French State has financed continuing professional training in the past, the 1971 law created new procedures and increased funds. In 1975, 57000 engineers and senior staff attended State-sponsored courses, about 6.4 percent of all employees receiving training from the State. Obviously most continuing education for engineers was financed by the firms.

The provisions aimed at an organized development of continuing education are intended to assure the right to education, and designed to systematize the administration of continuing education. As part of the right to education, employees are entitled to a leave of absence, subject to three conditions: they have worked for the firm for more than two years; they have not recently been granted training leave; no more than 2 percent of all employees, or 3 percent of all senior staff, are on leave at one time. Another right is continued pay during training, guaranteed by the firm for employees that it sends to training, or guaranteed by State monies paid to the business or directly to the trainee. And leave and remuneration are available not only for learning, but for those who teach as well.

It is difficult to assess the French Law's true impact on continuing education for engineers. When the law was introduced in 1971 continuing education was already well accepted in engineering circles, so it is difficult to fully appreciate the fresh growth of awareness which the new machinery has introduced, or the additional facilities which it has provided for the satisfaction of needs. Two surveys, conducted by the French engineering associations among their membership in 1970 and 1973 revealed that the percentage of engineers attending at least one training session in the last 3 years has remained constant at 56 percent. 


\section{Developing Countries}

In developing countries, the need for technician education and continuing education is far more critical than engineers' needs. These countries may use different ways of training technicians and keeping them up to date, depending to some extent on the country's type of economy and industry, structure and traditions of its educational system, and other social factors. In Africa, technician enrollments have trebled in recent years. In the Ivory Coast, for instance, there is a law which provides incentives for organizations to subsidize technician continuing education. It is different than the French Law in that it is an attempt to reduce the financial problem in continuing education, where the French $\mathbf{L a w}$ is more organizational in nature.

In some developing countries, industrial management downgrades the need for education of engineers and technicians. Strengthening of contacts between education and industry is now helping to change this by pointing education in directions more essential to economic development. Now these countries tend to structure their engineering and technician courses away from traditional disciplines toward areas such as mining engineering, public works engineering, rural engineering, environmental engineering, and maintenance. Since most of the population lives in rural areas, engineers and technicians need to be prepared to tackle rural problems. One country has set up a system of outlying technical schools, created and supported by local communities. They believe this will promote rural development.

Appropriate technology is an all important concern for developing countries. Because of the country's advanced development, graduate programs in the U.S.A. have been particularly negligent in teaching appropriate technology to people from developing countries. International students often return home from these programs as experts in superhighway design and computer operations and they find themselves with no way to apply their skills. Continuing education too must concern itself with appropriate technology. Courses should be practical and designed for specific resources. An engineer who can make a locally available high-bred clay is more useful than one who can design a high strength additive for prestressed concrete. Again, this points out the value of local involvement in designing continuing education courses, and the difficulty of transplanting in other cultures many continuing education activities.

National societies are important in aiding such local involvement, disseminating information, guiding education, providing means of formal and informal continuing education for their members, and acting as a link between education and society. Universities also serve many of these functions.

Throughout the developing countries, one of the highest priorities is given to teacher education, particularly in technical disciplines. The teachers must be kept up to date so that material presented to the students is up to date. Aid in this mission comes largely from contracts with developed countries and educational institutions within those countries.

\section{Financing ANd Sponsoring Continuing Education}

Throughout the world, so we have asserted, different models of continuing education develop to suit local conditions. In almost all countries of the world there are support programs so that individuals need not finance their own continuing education. Employing organizations usually pay the cost, and programs of government financing and mandated taxing programs do the rest. In the early history of western culture long-term professional development was considered a personal responsibility, and education was financed by the individual. Now the concept of a responsibility shared between employee and employer seems to be taking hold, generally with the employer providing most of the financial assistance and some company time. It is a reasonable projection to say the responsibility will continue to shift more to the employer. Employees will invest in less and less of their personal time and finances. The philosophy that "continuing education is a right" suggests a view of continuing education somewhat equivalent to undergraduate, primary, and secondary education.

Under the varying sets of circumstances, who should offer courses? Professional societies have a responsibility to the professional development of their membership. The employer also has a long-term commitment to manpower development. The universities have a responsibility to their graduates and to society. Further, and quite interestingly, entrepreneurs throughout the world are getting into the business of offering specialty courses and, in some cases, an extensive assortment of courses.

Somehow the universities have failed to meet their responsibility. So much has the academic community stressed research and peer group respectability, that continuing education and public service have a very low priority in most universities throughout the world. Faculty gravitate to research, graduate instruction, and self-aggrandizement through publications. In some European schools, the situation is even worse. Universities believe their responsibilities have nothing to do with continuing education.

Even though the climate in the U.S.A. does not seem entirely favorable to continuing education, a remarkable number of programs are offered by many institutions. Over 15000 courses are offered each year by American universities, serving over 400000 students. A significant number of institutions offer courses in Europe too, most engineering schools having some type of continuing education program. However, it usually is very small in comparison to the undergraduate and graduate programs.

UNESCO has recently brought out some telling figures in their Directory of Engineering Education Institutions. ${ }^{2}$ of the more than 450 degree awarding institutions in 64 countries of Africa, Asia, and Latin America, 96 answered that they have formal continuing education courses. Table I is a sample of the institutions, showing total attendances. Numbers listed are for the year 1973. Those responding have offered over 790 courses per year, serving approximately 15000 . Admittedly, this total is not complete, but it represents those institutions who were kind enough to respond to the questionnaire.

The universities have not always performed effectively in their continuing education role. Too often they inflict undergraduate or graduate courses upon practicing engineers, and produce great dissatisfaction in both students and instructors. Professional societies are generally more responsive, but often respond to needs only where large numbers are involved and program planning is less complex. Their strong point is in providing a good blend of practical instruction and theory.

\footnotetext{
${ }^{2}$ Directory of Engineering Education Institutions. Paris, France:
} The UNESCO Press, 1976. 
TABLE I

Partial Listing of Institutions in Africa, Asia, and Latin A merica Which Offer Continuing Education Courses

\begin{tabular}{|c|c|c|}
\hline Mame of Institution & $\begin{array}{l}\text { Number of } \\
\text { Forma } 1 \text { Courses }\end{array}$ & $\begin{array}{c}\text { Total } \\
\text { Attendance }\end{array}$ \\
\hline $\begin{array}{l}\text { University of Alexandria } \\
\text { EGYPT }\end{array}$ & 3 & 400 \\
\hline $\begin{array}{l}\text { Institut Universltalre de Technologie } \\
\text { Industrlelle, MADAGASCAR }\end{array}$ & 20 & 30 \\
\hline $\begin{array}{l}\text { Ecole Mohamadia d'Ingenleurs } \\
\text { MAROC }\end{array}$ & $I$ & 50 \\
\hline $\begin{array}{l}\text { Indian Institute of Technology } \\
\text { Bombay, INDIA }\end{array}$ & 26 & 698 \\
\hline $\begin{array}{l}\text { Islamic University Sultan Agung } \\
\text { INDOWESIA }\end{array}$ & 7 & 42 \\
\hline $\begin{array}{l}\text { Kon-Kuk University } \\
\text { REPUBLIC OF XOREA }\end{array}$ & 5 & 40 \\
\hline $\begin{array}{l}\text { Polytechnical Institute of Mongolla } \\
\text { MOMGOLIA }\end{array}$ & 1 & 150 \\
\hline $\begin{array}{l}\text { University of Mindanao } \\
\text { PHILLIPPINES }\end{array}$ & 8 & 200 \\
\hline $\begin{array}{l}\text { Chulalongkorn University } \\
\text { THAILAND }\end{array}$ & 11 & 300 \\
\hline $\begin{array}{l}\text { Universidad Hacional del Sur } \\
\text { ARGEKTINA }\end{array}$ & 20 & 150 \\
\hline $\begin{array}{l}\text { Pontificia Universidade Catholica do } \\
\text { Rio de Janerio, BRAZIL }\end{array}$ & 42 & 498 \\
\hline $\begin{array}{l}\text { Universidad de La Habana } \\
\text { CUBA }\end{array}$ & 36 & 415 \\
\hline $\begin{array}{l}\text { Universidad Technica de Ambato } \\
\text { ECUADOR }\end{array}$ & 5 & 80 \\
\hline $\begin{array}{l}\text { Universidad Iberoamericaca } \\
\text { MEXICO }\end{array}$ & 4 & 90 \\
\hline
\end{tabular}

In Europe, professional societies have more continuing education courses than universities. One-week short courses and state-of-the-art two-day seminars are particularly popular. The same is true for much of Asia. Most often programs are run in full cooperation with the universities-an excellent way to run programs.

\section{THE EMPLOYER}

The employer is in the most opportune of all positions to identify needs and respond to them with the most cost effective educational programs. Again, course offerings must be limited to those subjects where sufficient numbers are involved. More specific needs, for instance where only two or three employees have a similar need, may have to be served by professional societies or universities.

Employers throughout the world find employee continuing education a part of doing business. Some view it as vital to their product line, to staying on the forefront of technology; others view it as part of an equitable program for human development. Still others view it as a fringe benefit. In the broadest definition of continuing education or professional development, the employer probably accounts for threequarters of the activity, including reading of technical journals, job assignment rotations, various management and technical continuing education courses, and tutorial interchange between staff and colleagues. No matter where continuing education comes from, it is important that the employer be involved in planning and subsequent development. The educational experience will be far more productive if the recipient has put what he has learned to practice-the ultimate evaluation of continuing education effectiveness.

\section{Methods of Continuing Education and the USE OF MEDIA}

By far the most effective formal means of continuing education in almost every country is still the lecture method. The informal method of reading textbooks probably surpasses the lecture as a means of knowledge transfer, but the lecture offers more opportunity for instant update. You can use it in short courses, seminars, evening classes, and hour-long presentations at engineering clubs. One-week short courses and one-to-threeday seminars, popular throughout the world, incorporate some visual techniques, but the lecture method is still the educational mainstay.

Satellites were seen as a boon to international engineering education, but the costs have proven too high and the clientele far too small in comparison to general interest subjects. They have been used for educational purposes more often in the fields of education at the primary, secondary, and teacher educational levels. Only on an experimental basis have satellites been able to play an important part in engineering continuing education.

There is also a surprising lack of correspondence courses, which have the tremendous advantage of self-study and independence of location. The University of Wisconsin has approximately 50 courses with an enrollment of 2000 people per year, about 10 percent from at least 20 different nations. There are many correspondence course programs with similar experiences. But again there seems to be a problem of keeping subject matter current as well as getting enough engineers to participate. Correspondence has not been a leading method of continuing education, as it first appeared it might be.

Videocassettes, television, and other mediated instruction have also shown only uncertain success in international engineering education. There are examples in the U.S.A. where they have performed well, but only where both faculty and potential students are sufficiently concentrated. Some organizations sell packaged video programs, for instance in Japan. At a fairly reasonable cost you can buy courses developed at MIT and elsewhere. However, mediated instruction still plays a very small part in the total continuing education picture. If multimillion-dollar capital investments are to be made, the enrollments will have to be very significant, and the benefits to students more cost effective than the lecture method.

On the fringe of continuing education there are many other formats and media that can and are being used, such as radio, discussion groups, tutorial, self-study. All are important in the general area of information transfer but do not have a major impact on continuing education of engineers.

\section{What CAN WE LEARN?}

One principle that is quickly learned in an analysis of continuing education around the world is that courses are seldom transferable from one country to another. There have been many examples of successful course transfer, particularly with local expertise involved, but attempting to serve a world market with a single course package is a mistake. A byproduct of the famous Open University in the United Kingdom was 
believed to be a worldwide market for materials they had developed. The market proved much more restricted than they had anticipated.

Based on the statistics from the socialist countries, external students who depend heavily on self-study are decreasing in numbers as full-time study opportunities increase. This report implies that external and extramural studies, though cost effective, require a lot of self-study and consequently lack appeal.

So far, experience with the French Law indicates that mandatory financing does not necessarily increase the participation of engineers in continuing education. The reason for the law was to make continuing education available to all and the presumption was that the numbers involved in continuing education would significantly increase. This did not hold true for the engineering profession. Based on this experience, it is doubtful whether mandatory continuing education for licensure would have any positive effect on participation in continuing education.

Short courses, seminars, and evening courses continue to be the most popular forms of continuing education throughout the world. The effective media can have some very beneficial local impact but on a global basis they do not appear to be the solution to continuing education for engineers.

All in all, continuing education is more highly regarded at this point in time than ever before. Many nations who once thought it a frill now see it as an important part of educational planning and economic development. The rate of growth throughout the world is high, and the future looks very promising.

\title{
Media-Based Continuing Engineering Education
}

\author{
(It's the Engineers', University's, Industry's, and Professional Societies' Responsibility)
}

JOSEPH M. BIEDENBACH, FELLOW, IEEE

Invited Paper

\begin{abstract}
Continuing education activities in universities and within companies themselves have shenomenal growth over the last decade because of the economic competition faced by business to utilize the most recent technology avilable to them. Engineers and scientists have, as have all citizens, had to cope with this changing technology and the pressures of greater productivity required of them.

This paper deals with the interfaces between the individual working in business and the universities, profescional societies, and industry to help them maintain their professional competence throughout a rapidly changing career. Individual motivation to maintain a leaming attitude and the willingness to accept new techniques is a paramount problem to lifelong leaming. The time constraints, cost, availability of programs, and the necessity to set individual goals are a few of the problems facing the professional today. This paper addresses the programs being developed by industry, universities, and the professional societies. Emphasis on the IEEE programs are an example of how the professional societies are attempting to meet the needs of their membership.
\end{abstract}

Manuscript received August 15, 1977 ; revised January 17,1978 .

The author is with the College of Engineering, University of South Carolina, Columbia, SC 29208.

\section{INTRODUCTION}

\$ EFORE one begins to discuss continuing education for the engineering and scientific professions, he must have a well thoughtout philosophy of continuing education. Over the past decade continuing education has become vitally important for anyone in an engineering or scientific field. It is obvious that the technological explosion and the competitive environment for consumer products which prevails in our society, and the accompanying necessity for greater productivity for all those in our working society, makes it mandatory that the engineering departments of industry become much more productive. This places a great strain on the individual engineer's personal time, and if he is working in industry, on the engineering manager's budget who must be concerned with a short-term profit goal for the department involved.

In any context, education is hard work. One cannot learn a new technology, remain abreast of the existing technology, or relearn things forgotten without great effort. If one considers 